\title{
Gender, Sexuality, and Intimacy in a Women's Penal Colony in Russia
}

\author{
Elena Omelchenko \\ Professor, Director of the Centre for Youth Studies, National Research University \\ Higher School of Economics, Saint Petersburg \\ Address: Ulitsa Soyuza Pechatnikov, 16, Saint Petersburg, Russian Federation 190008 \\ E-mail: eomelchenko@hse.ru
}

\begin{abstract}
This article explores sexuality and intimacy in a women's penal colony in Russia. Russian researchers rarely focus on the Russian prison system as a whole, or on women's experiences in colonies, female identities, and punishment practices in particular. These topics therefore remain marginalized, out of the spotlight of critical public debate and sociological research. The present article contributes to the current debate on the meaning and consequences of close relations in women's colonies, varying in context from friendship and love to exploitation under the tough control of the gender regime from both the prison administration and the informal system of power typical of a prison hierarchy. The female body becomes an additional mechanism of supporting the repressive nature of a penal colony, strengthening patriarchal traditions, and maintaining a high level of homophobia in Russian society as a whole. Based on the analysis of 33 in-depth interviews including biographical elements with women between 18 and 55 years old convicted for various crimes, I argue that the gender regime in correctional facilities for women becomes an additional mechanism aimed at strengthening discipline, control, and the patriarchy in a patriarchal society. Whilst the regime is not prescribed by law, it becomes the law because of the extreme objectification of women, the female body, and the status of the female.
\end{abstract}

Keywords: Russian prison system, women's colonies, patriarchal gender regime, female body, gender, sexuality, intimacy

\section{Introduction}

The prison experience of isolation, correction, and excessively-regulated bodily discipline not only adjusts and deforms the modes of intimacy (physiological, psychological, and sociocultural), but also makes their analysis complicated. Social researchers discuss the interdependence between sexual practices in society and prison sexuality. There is also a connection with the experience of numerous other countries where homosexuality was considered "criminal" and was punished by law, as it was in Russia (Healey, 2002). The Russian context is dominated by patriarchal regimes (Temkina, Zdravomyslova, 2014) and homophobia, peculiar features of Russian society (Stella, 2008; Wilkinson, 2013; Essig, 2014; Stella, Nartova, 2015; Omelchenko, 2015). The topic of this article requires that

(C) Elena Omelchenko, 2016

(C) Centre for Fundamental Sociology, 2016

DOI: $10.17323 / 1728-192 \mathrm{X}-2016-4-76-95$

* The article was prepared within the framework of the Academic Fund Program at the National Research University Higher School of Economics (HSE) in 2015-16 (Grant No 15-01-0154: "Distinctions, Exclusions, and Adaptation in the Russian Colony"), and supported within the framework of a subsidy granted to the HSE by the Government of the Russian Federation for the implementation of the Global Competitiveness Program. 
both the gender regimes in Russia and the logics and structures of prison subculture be taken into account.

At the beginning of 2014, Russian correctional facilities for adults contained 650,600 people, including 720 penal colonies where 526,300 people (including 42,300 women) were serving their terms (FPS, 2016). This is one of the highest rates in the world (Yasaveyev, 2010). Sociological research rarely focuses on the Russian prison system as a whole and even more rarely on women in colonies (Piacentini, 2004; Pallot, 2005, 2010; Pallot, Piacentini, 2012; Piacentini et al., 2009; Moran et al. 2009; Katz, Pallot, 2010; Moran, Pallot, Piacentini, 2013; Pallot, Katz, 2014; Omelchenko, 2012). The main reason is that the image of a convicted person is subject to comprehensive social stereotyping and marginalisation in contemporary Russian society (Omelchenko, 2015). Female prisoners are at the very bottom of the social hierarchy. Punishment practices and female identities in colonies remain marginalized and exoticized, out of the spotlight of critical public debate and social research.

This article focuses on the analysis of gender hierarchies and sexual practices that emerge in Russian penal colonies, in the context of isolation and punishment. It argues that the gender regime in correctional facilities for women becomes an additional mechanism aimed at strengthening discipline, control, and the patriarchy in a patriarchal society. Whilst it is not prescribed by law, it becomes the law because of the extreme objectification of women, the female body, and status of the female. At the same time, women find resources for subjectification (among other things, through the tactics of adjustment and resistance in the forms of partnerships, families, and sexual relationships), creating an intimate and private space in the public context of tough control and discipline.

\section{Female Intimacy in the Prison System: Lines of Theoretical Research}

The construction of gender regimes and sexualized relationships in correctional facilities is closely connected with the study of similar phenomena in other isolated social systems, such as assisted-living facilities, monasteries, and so on. Some of the most important aspects of this issue are the formal and informal boundaries between the private and the public in isolated systems, bodily control and discipline (physiology, hygiene) through corporal punishment and rewards, the influence of a homosocial environment on emerging emotional relationships, and the idea of humanism in the context of confinement.

The first early-190os study of sexuality in women's prisons used such terms as "perverse relationships" and "abnormal tendencies" (Hensley at al., 2000: 360-367). In 1934, Joseph Fishman, a former inspector for U.S. federal prisons, wrote: "We are living in a frank and realistic age, yet the subject of sex in prison-so provocative, so vital, so timely ...-is shrouded in dread silence" (Fishman, 1934: 5). There is research (surveys) that focuses on various forms of close relationships (including sexual practices) among women in correctional facilities (Lauren, Hensley, 2013). This research has revealed such forms of relationships as friendship, play families, pseudo-homosexual relationships, and 
lesbianism (Ward, Kassebaum, 1964). However, the topic of prison sexuality is still ignored by both society and sociologists (Hensley et al., 2000: 361 ).

Most recent studies are aimed at exploring violence and aggression, (both covert and direct), which has resulted in the dominant opinion that close relationships between female inmates usually take the form of sexual exploitation. This research has both followed and increased dominant discourses and policies of punishment, placing an emphasis on the extreme deprivation of privacy as the basic principle of correction. Research on female victims of sexual harassment and violence in correctional facilities has become a powerful mechanism for the development of this approach (Baro, 1997; Struckman-Johnson et al., 1996). However, works on this subject are still few in number. It is especially evident in the empirical material, which often leads to unfounded conclusions, and the use of popular, stereotypical images and scandalous, almost pornographic, texts.

Even after the criminal penalty was repealed, the concealment and taboo of these practices were reinforced by academic and popular discourses which presented the "prison origin" of homosexuality as a consequence of forced isolation (Kunzel, 2008; Mondimore, 1996). The Russian scientist, Igor Kon, holds a important place in the research and analytical work on the decriminalisation of homosexuality in Russia (Kon, 2003).

Furthermore, importation and exportation theories linking sexual practices in correctional facilities with women's experience in their life in general constitute a separate line of research. There are works that deal with the idea that prison sexuality is determined by the importation of one's previous (pre-prison) sexual identity. Other works focus on the influence of prison practices on inmates' sexual behaviour after their discharge. These studies point out that the exportation of prison identities and practices can influence social norms about sexuality, including masturbation and homosexuality, in wider social environments (Lacombe, 2008; Smith, 2006).

The work of Angela Pardue and her colleagues on the typology of sexual practices and sexuality in correctional facilities for women (Pardue et al., 2001) proposes the classifications of suppressed sexuality, autoeroticism, true homosexuality, situational homosexuality, and sexual violence. Each category is characterized by the level and type of sexual involvement, as well as by a corresponding degree of potential violence.

The suppression of sexuality may be an adaptive response to the prison environment, and not a result of sexual dysfunction. The researcher Kimberly Greer refers to the results of the analysis of 35 in-depth interviews with women, and argues that intimate relationships in prisons for women are characterized by an atmosphere of distrust (Greer, 2000). Most studies that deal with female sexuality in prisons focus on same-sex relationships and the formation of play families. Research in European and American academic communities on homosexual relationships among female inmates was given very little attention until the 1960-1970s. Thus, compared with homosexuality in male prisons, lesbianism was considered trivial and harmless. Homosexual relationships among prisoners may be described as "true," typical of those women who have identified themselves as lesbians prior to imprisonment, or "situational," which a woman only experiences in prison due to the absence of heterosexual opportunities (Pardue et al., 2001). "True" homosexuality 
is attributed to the importation model, while "situational" homosexuality is explained through the model of deprivation and isolation.

Some authors list the following roles and statuses among those emerging from female same-sex activities: butch, femme, trick, commissary hustler, square, and cherry (Ward, Kassebaum, 1964: 168). The butch, stud broad, drag butch, or daddy have a distinctively masculine appearance and are usually the dominant partner in same-sex relationships. On the other hand, the femme or mommy has a feminine appearance, plays a passive role in the relationship, and acts in a manner that corresponds to what is considered as traditional female behaviour. Tricks are the least respected inmates as they allow themselves to be sexually exploited by others, while commissary hustlers maintain long-term meaningful relationships with some prisoners while exploiting or manipulating others at the same time. Cherries are inmates who have never engaged in same-sex intercourse, whereas squares refuse to participate in homosexual behaviour. It is obvious that female prisoners can be subjected to various types of socially dangerous behaviour, such as harassment, assault, and rape.

Some researchers point out special (and even more discrete) types of sexual interactions that develop between female inmates and the staff of correctional facilities. Prisoners can manipulate and even coerce prison staff to engage in sexual activities in order to receive special treatment for a variety of reasons, such as pleasure, trade, transgression, procreation, safety, and love. In addition, convicts may view sex as an expression of freedom, especially as sexual intimacy is one of the few aspects of their lives that they can control. For instance, some say that sexual interactions with correctional staff "is the ultimate way to thwart the system" (Smith, 2006: 192).

The analysis of the construction of specific types of masculinity in colonies for women is promising not only for the topic discussed in this article, but also in the wider context of gender studies in general. The data presented in this article can be used to continue this analysis, thus expanding the boundaries of the description of different sexual/gender displays in correctional facilities for women. The following analysis relies on the abovementioned positions in order to test the ways they manifest themselves in the Russian context.

The analysis of the current academic agenda gives us an opportunity of critical involvement in the theoretical debate on the nature of prison intimacy. Most of such studies focus on finding violence and aggression, (both covert and direct), which results in the dominating opinion that close relationships between female inmates mostly take the form of sexual exploitation. The concealment and taboo of these practices were reinforced by academic and popular discourses about the "prison origin" of homosexuality as a consequence of forced isolation (Kunzel 2008; Mondimore, 1996) which promotes the dominant discourses and policies of punishment, laying an emphasis on the extreme deprivation of privacy as the basic principle of correction.

The lack of research on everyday life in women's prisons that would reveal the entire palette of friendship, love, and trust scenarios leads to the replication of stereotypical scandalous, almost pornographic, images of a female inmate. The present article also 
contributes to the debate between advocates of the importation and exportation theories: one claims that prison sexuality can be explained through the importation of one's previous (pre-prison) sexual identity (Irwin, Cressey 1962), while the other focuses on how prison practices influence one's sexual behaviour after discharge, affecting social norms in different social environments of the society as a whole (Lacombe 2008; Smith 2006). A detailed analysis of women's narratives allows us to offer an extensive analysis of the models of intimacy beyond the scope of importation and exportation theories' explanations of privacy.

\section{Penal Colonies and Social Research in Russia}

In Russia, the subject of prison is still taboo; it is simply off-limits. It is extremely difficult for researchers to gain access to correctional facilities. The Russian penal system is guarded, both literally and metaphorically, as one of the last bastions of Soviet-style punishment and correction (Omelchenko, 2015). Russia has its own contexts of the "prison issue." Historically, it is associated with the legacy of the punitive, repressive system of the Gulag (Pallot, 2005). The institutional context reflects the current situation in the penal system. The social policy is aimed at disadvantaged groups of the population, where previously-imprisoned women are not a priority (Omelchenko, Sabirova, 2013). Finally, there is public opinion that stigmatizes prisoners (Yasaveev, 2010).

There are 35 female colonies in Russia today. First-time female offenders are sent to prison less frequently than male offenders. However, they are not treated leniently if an offence is committed for the second time, especially if it happens during the parole period-hence, the large percentage of recurrent prisoners among women in colonies. Analytical texts underscore a change in the structure of female criminality (the proportion of violent crimes is increasing) as well as the feminisation of crime, which is viewed as a threat to the well-being of society. Research that emphasizes the individual criminological features of women is involved in the production of panic around the "deteriorating moral image of a woman."

In Russia, the research surrounding sentenced women, their criminological features, factors affecting crime rate, and inmates' re-socialisation after discharge is carried out by criminologists (Antonyan, 2009), psychologists, teachers, and (more recently) social workers. Researchers often resort to questionnaire-type surveys which address very specific disciplinary tasks, whereas the everyday life of women in prisons and colonies is often side-lined. Sociological and cultural studies of everyday life in prison are scarce (Gusejnova, 2013, Oleynik, 2001), especially those that represent convicted women (Alpern, 2000, 2004; Tishchenko, 2007). Three discourses can be distinguished in the current Russian academic tradition of female crime and post-prison rehabilitation research: medical, psychological, and criminological. All of these discourses regard female criminals as a pathological phenomenon in that they are unable to control themselves and exhibit "unnatural" features. The criminological discourse on female criminality is a kind of a bastion of authorized gender stereotyping, and the production of moral expectations 
and accusations aimed at women. The range of social phenomena that shapes the identity of a female criminal is defined in terms of a psychological/medical pathology, or through the concepts of distress, deviation, and asocial behaviour.

There are practically no Russian works on sexuality in prison, except, perhaps, those of Lyudmila Alpern. However, her texts rarely touch upon the topic of close relationships in correctional institutions for women, and they are mostly done in the context of human rights, not sociology. It should be pointed out that, overall, gender issues in Russia meet a number of difficulties, and research on (homo)sexuality is becoming a taboo subject. In their description of the modern neoconservative turn in Russia, Elena Zdravomyslova and Anna Temkina, known researchers of gender regimes in Russia, underscore the strengthening patriarchal discourses and practices in modern society (Temkina, Zdravomyslova, 2014).

Sexuality became the subject of theoretical thinking and empirical investigation in the USSR only in the 1970s. Discussion of the topics of sexuality and sex were taboo, and the saying "There's no sex in the USSR, there is love" became a catch phrase. The unavailability of professional discourses, the public silencing of sexuality, and the absence of education and of public discussion of sexual practices shifted sexuality into the sphere of shady folklore. The Soviet discourse of sexuality was hypocritical (Omelchenko, 2015). In the period of Gorbachev's Perestroika (1985-1991), when there was weakening state control over all spheres of society, the perception of sexuality in public discourse changed. In Russia today, despite the public declarations of the state and political leaders against sexual discrimination, we observe that there is a widespread policy of homophobia, which is promoted as an expression of anti-Western orientation. There is a growing conservatism in Russian society accompanied by the increasing influence of the Orthodox Church in regard to the formation of new paradigms of bringing up children and the education of youth, silencing issues of sexuality (Omelchenko, 1999, 2000, 2015; Stella 2010).

\section{Methodology and Empirical Data}

This article is based on the secondary analyses of the data and was conducted within the project "Differences, Exclusions, and Adaptations in a Russian Penal Colony." The empirical data was gathered as a part of the project "Return: the Post-Penitentiary Experience of Young Women." The empirical study was conducted in four Russian cities: Saint Petersburg, Ulyanovsk, Nizhny-Novgorod, and Saratov. The selection of both capital and provincial cities was determined by the restricted access to this research field and by the initial hypotheses. As the interview collection presents women from different colonies, it helped to avoid homogeneous data. The interviews were conducted between 2011-2012. A total of 33 interviews were conducted with women between the ages of 18 and 55 years-old who had been convicted for various crimes (drug sales, theft, fraud, murder), either for the first time or as a repeat offender, and having been discharged in the last three to five years. On average, the interviews with biographical elements lasted 1.5 to 4 hours. More than half of the informants had previously used hard drugs. There 
were also women infected with HIV, hepatitis, and tuberculosis. It is obvious that such a difficult field required an additional effort to find women with such experience and to obtain their consent. Informants were recruited through researchers' personal contacts and using the "snowball" method, with the help of the social and personal networks of the informants themselves. Social-security authorities, psychologists, and social workers involved in various inmate rehabilitation projects rendered some assistance in conducting the interviews.

To cover the research topic more thoroughly and to understand the rehabilitation field, ten expert interviews were conducted with the staff of crisis centres for former prisoners, representatives of social services, doctors, psychologists, social workers, or law enforcement officers, that is, the professionals from various rehabilitation and adaptation programs for women released from prison. The women's narratives were analysed according to "grounded theory." We took into account that some elements of the women's stories were targeted at the researchers. Even though sexuality is a sensitive topic, the women were quite open. We acquired a whole range of stories from different representatives of the hierarchy, displaying various ideas about sexual relations in the colony. Due to certain limitations of this method of studying gender and sexuality, the sample and analysis did not present many situations or practices of violence.

\section{Body, Hierarchies, Guardians}

This section describes the important contextual circumstances that define intimacy practices in colonies. Here, practices of bodily control, social hierarchies that emerge in colonies, and relations with the guards are all touched upon.

Conditions in prisons vary, but most often they are demeaning and harmful to women's health and dignity. Such conditions are the low professional level of gynaecological care, the degrading practices of medical examinations, the absence or lack of sanitary materials for menstruation, unjustified prohibitions, severe punishments for soiled bed sheets and a lack of opportunity to wash them (only at night or during work hours), and the need to hide blood-stained sheets and underwear in order to avoid being abused by guards and ridiculed by neighbours. Problems with both hot and cold water make it virtually impossible to maintain personal hygiene during menstruation. Basic hygienic conditions present real problems. "Toilet collectivism," a carefully protected additional mechanism of stripping inmates of their dignity and completing the destruction of their private space, is probably one of the most amazing discoveries of the Soviet penal system:

These foreigners should come here and try to use the toilet here! All the restrooms have been renovated, "European-style." Why the hell do we need this "European" crap? The restroom is all white and beautiful ... and no doors, nothing. Mirrors everywhere.... and the wash space has three washbasins for 120 people. ... people are standing there, in front of the mirror, putting their mascara on, while you are trying to do your thing. I can get used to anything, but this beats me! I don't get it: 
okay, you took away my freedom, but why do you think that it somehow changes me physiologically? That I can see in the dark, that I can wash without water?!

(Lyuda, 55, prison term: 2 years)

Staff in female prisons are free women who hold a special place in the inmates' stories. They are guards, medical staff, heads of administrative departments, and checkpoint and inspection point officers. They appear in stories about additional humiliations that start with the first inspection after the verdict and includes the tolerance and support of informal fights between women in the cells and barracks, as well as covering up for those who are loyal to the administration and perform additional supervisory functions. The peculiar power regime, reinforced by a homosocial environment and interconnected formal/informal gender hierarchies, makes women's female problems seem even tougher. These regimes are built into the hierarchical homosocial penal system, where the exploitation of female physiological features becomes an additional resource for the repressive patriarchal power.

Social hierarchies that develop in colonies, and, consequently, the distribution of power, are important for looking into gender and sexual relations. Interpretations of various status positions may vary, but it is possible to distinguish the following categories:

(1) Blatnye: unit and brigade leaders, those who have connections with security guards or prison authorities. They have the right to monitor relationships between inmates and have to report violations, which means that they have informal power, deciding what and who to report and who to hold in fear.

(2) "Sherst": inmates that have real privileges connected with their pre-prison status that includes rich relatives, frequent care packages, and support from the administration.

(3) Activists: those who try to earn their parole establishing a second, self-organized, authority system in a colony (voluntary discipline and cleanliness checks, or participation in amateur performances).

(4) "Griby": the lowest caste in the prison hierarchy. These are the inmates who have been in prison for a long time such as homeless people, alcoholics, or women from extremely poor environments and rural areas that do not receive care packages.

(5) Those with the lowest social background before incarceration who are known as the "Gorokhi," the "youngsters," the first-time inmates without the social or psychological resources necessary to fit into the existing system. "Griby" and "gorokhi" are used (forced) or employed to carry out service work for the blatnye, such as tidying bedrooms, cleaning wash spaces and toilets, and so on. This work may be done in exchange for protection, out of fear or in return for a fee (normally not for money, but for necessities such as cigarettes, coffee, tea, sanitary pads, or clothes).

It is important to point out that this hierarchy is supported and encouraged by the administration: 
So, they are blatnye; they have everything, like, a position; they are first everywhere. God forbid you go against them. They live in comfort, everything's lined upwith the police, with other inmates. Everyone knows and remembers them. And "sherst"- they stand out anywhere; they are blatnye in female prisons. Those who have a certain status even without those, activists.... So, if you are chosen to be an activist, you automatically butt in everywhere, you have an easier time, like, smoking when and where you normally can't ... And then, there are so-called "griby." Some don't even treat them like human beings, while they are mostly just kind, pure people. Even if they are somewhat weak in the head. They don't have this nastiness in their soul. And activists all work just to get parole.

(Galya, 36, prison term: 3 years)

A parallel, sometimes alternative, hierarchy emerges among those who receive care packages and those who do not, i.e., it depends on one's economic status and support received from one's family. Here, one inmate recounts a story of a young girl who had special treatment in prison because she had very rich parents who constantly sent her care packages, and actively helped the colony:

They came from the city of Nefteyugansk to visit her every month, they sent her packages every month, gave money to some woman to bring those packages ... She had bags full of stuff; she lived large. Her mother installed computers in every office ... all the curtains in the unit, everything-her mum, her mum, her mum, as long as her daughter doesn't get sent to the isolation cell; so, there you go. ... she plays family with some people, then leaves them for others; there was a fight for her in prison, for her stuff. People didn't like her, but they played nice, tried to win her over because of her bags.

(Yulia, 37, prison term: 8 years)

\section{The Right to Love, and "Boys" in Women's Penal Colonies}

The research has demonstrated that the inner structure of penal colonies for women is largely defined by the interconnections between sexual and gender dimensions and power relations whereby a variety of forms and types of inmates' relationships with each other and with the administration are integrated into the existing hierarchy.

The gender display in colonies is incredibly varied, contradictory, and complicated. According to the regulations, there is no gender in prison:

Here, these are her [prison warden's] words: "Inmates have no gender." We are inmates. That's it. When we told her, "We are women, we need to shower. Do you understand?" She said, "Inmates have no gender." And that's it; it doesn't matter, you are inmates. Who are you? Men, women-it doesn't matter.

(Oksana, 33, prison term: 5 years 3 months).

The research encountered different, sometimes contradictory, interpretations of male (masculinized) images and sexual/gender interactions in the women's penal colony. They were defined not only by an informant's status and her views on homosexual relation- 
ships, but also by implicit codes of honor in different colonies, their features of gender regimes, and the administration's attitude. For instance, romantic stories about relationships between inmates and female guards mean that homosexual couples are considered normal in this particular colony, even if it is not talked about. On the other hand, informants from colonies where the unwritten laws follow official regulations more closely say that such women are caught, punished, and put in punitive isolation cells.

The right to love is also connected with the status of those who love and are loved. For instance, blatnye, activists, and "sherst" can practically live openly as couples, while "griby" and "gorokhi" do not have the right to do so. We see that the degree of an inmate's security and her right to private (personal or intimate) space and time, as well as her everyday practices, directly depend on different hierarchy combinations. It was not always easy to understand which branch of power has the most influence. Those loyal to the administration are in the most secure position, and vice versa. However, no positions are stable and permanent. The lives of activists, blatnye, and "herst" depend just as much on the attitude of other inmates towards them. Emerging oppositions and, consequently, "more problems" for a colony's administration can trigger instant reconsideration of the situation and switch the positions of its main actors. This fragility and instability of any status, except perhaps for the lowest ones, becomes an additional mechanism of maintaining an atmosphere of fear, mistrust, and insecurity.

Women who expressly define themselves as men are called patsany ("guys") in colonies. Despite the prejudice that this image is used solely for personal gain, each prison history mentioned a "guy." They are usually described as follows: cropped hair (or bald), dressing up "like real men," their body language and facial expressions correspond to the image, and they work as prison electricians, plumbers, and equipment adjusters. Their gender performance has clearly sexual connotations. They present themselves as sexually active, experienced "men" who are ready to have sexual relations with women and to take the dominant role:

God help you if there is an inspection; the unit leader might get it in the neck ... "Come on, wear the uniform." - "I don't want this headscarf, I'm a guy." These "patsany" are usually bald: "I'm a tough guy." Curtains; they shag girls all day long, don't do shit-not a single thing,- don't care about anything ...

(Nadya, 34, prison term: 9 years)

The patsany community has its own unspoken rules. Habitual offenders are treated with more respect because they know everyone and everyone knows them; they have a certain reputation, gender, and sexual history. Some young first-time offenders cut or shave their hair to raise their status, but they are usually crack very soon. To pretend to be a patsan to get "undeserved respect" is considered to go against the rules.

Despite their tough macho image, patsany are still women. Women who lived in prison as couples say that only "first-timers" try to look like a man; they think that it is customary, but it does not matter in real couples. Such "guys" are in demand; they help 
women to keep in shape, take care of their appearance, fantasize, act out romantic stories, create "fictive" families, and fulfil their need in emotional support:

Some love those "studs": "I'm so girly, I'm in love." She is putting make-up on and doing her hair all day long; it's like mating season, she's in love. Everybody falls head over heels in love with those bald "guys." Well, basically, yes, their life is easier—girls feed them. For love.

(Nadya, 34, prison term: 9 years).

The women's stories also mention the image of an old patsan, or "old man." Generational hierarchies are quite important in colonies. On the one hand, old female convicts have certain advantages: they do not work, they receive retirement benefits, and they can relax. On the other hand, they can trigger negative reactions: they usually serve longer terms for murder; it is harder for them to look after themselves, so they are held in contempt as "dirty slobs," which is an important factor of hierarchy formation in colonies for women. Consequently, most inmates describe their sexual relations in a condescending manner:

They are so sly, you know. These old women are the filthiest, with their washbasins with clothes soaking there for so long they turn sour. They are usually old alcoholics; they are dirty, they have epilepsy, fits, and they still manage to shag each other, to make each other jealous. Well, one is shaking with an epileptic seizure, and another is at watch: (sings) "We while nights away ..."-she will come to feel up someone else on purpose. They do all kinds of things, these old women and "men."

(Nadya, 34, prison term: 9 years)

\section{Intimacy in Women's Colonies}

The topic of "families" is a key point in the research and descriptions of female relationships in correctional facilities in different countries. "Fictive" families, couples, and close partners (semeynitsy) are particular (although not necessarily sexual) social forms that help women cope with the everyday problems of deprivation and isolation. It is a sort of agreement on joint household and emotional work, where mutual favors are defined not only by inmates' desires, but also by the rules of a given prison or colony. For instance, certain hierarchies emerge among families, according to the status of couples:

I'm in a couple ... so, I am waiting for my girl. She kind of switched, too. Those with longer terms, they kind of find a partner, so to say. And when you live with someone, it is easier to go through it together. Those who are visited by their husbands, they are on their own, yeah. And mostly, you know, loners-they don't have any visitors. . . . there are those who do it occasionally, for a care package. So, for example, she gets packages. She will make her fall in love with her, and that's it-she uses her. There are many women, manlike, you know; sometimes you can't even tell if it's a boy or a girl. They usually live at other people's expense. ... And there are many couples that are actually based on love.

(Zhenya, 28, prison term: 6.5 years). 
Another form of close relationships is the "vzaimka," a relationship of mutual support, aid, and assistance. Such relationships may include sexual intimacy, and the name is supposed to exclude them from the prohibited space, to avoid discussions of a sex change or switching one's sexual orientation. Women in these relationships do not designate who is the girl and who is the "guy":

\begin{abstract}
Most often, people have "vzaimka." Two girls live together, sleep together, and they are just girls who help each other. Everything they show in films is rubbish.... It is crazy, shame on them! And it is outdated now; of course, we laugh at these "guys." "No, I'm surely not a man,"- this is much more popular now. "I'm a normal person, it's just the way I look." ... Just a woman, like me, just like me. It's all bullshit that they do it in some special way ... grinding on a leg. They caress each other like others do ... prison makes them hungry [for sex], there is an edge to it, many want some. Someone, like, some men come to your prison to work there-everyone flocks around them, and so on. And others-mind your business; girls are just friends, you know. They are husband and wife?! No, it is laughed at, it's not like that...
\end{abstract}

(Nadya, 34, prison term: 9 years)

Another woman was trying to find the right words and definitions for her and other inmates' relationships in the course of the interview, while trying to figure out the extent of risk that faces women in homosexual relationships with no such pre-prison experience. It is obvious that this question did not just arise in the course of her conversation with the interviewer, and that neither in prison, nor during the interview could she find the exact and correct terms to distinguish true feelings from exploitation, emotional and household assistance, and support:

During my first time in prison, there was this really forgiving colony warden; the only thing he used to put us in punitive isolation cells for was precisely this, lesbianism. ... Since I'd had some sexual experience with a woman before prison, yes, back then I wondered what his problem was-who cares? And now, in hindsight, I see that this guy was really wise, because the consequences are so terrible ... It's one thing when it's free and consensual, and it's completely different when it happens out of hopelessness, because your maternal instinct requires application. ... And I myself have a partner, we have been together for 22 years ... she used to have nothing to do with crime. And then, at some point, she broke down and began to shoot up, so, she got here, too. But we are together. There you go.

(Lyuda, 55, prison term: 2 years).

These quotes show how contradictory and overlapping relationship concepts, images, and names can be. This secretive contextual knowledge, which makes it difficult for outsiders to see the true meaning, is, to a great extent, a response to the continuing stigmatization of close relationships not only by prison administration, but also by many women. It has to do with the closed nature and latency of many practices, not only for fear of disclosure, but also because of the problems of sexual identification in isolation, complicated 
by the regime, and in addition to popular discourses that criminalize female intimacy in correctional facilities, viewing it as entirely situational, "fake," and "abnormal." We did not find any definitive distinctions between cohabitation types designated with different names. For example, "semeynitsa" may mean both "a couple" and a "vzaimka."

At the same time, not all women are part of a couple or a family, since some simply have meals together ("odnokhlebki"):

Yeah, I'm alone. I have breakfast if I want to, or maybe I don't; breakfast with you, dinner with her, and for lunch I can just drop by, have a bite of bread and sausageI have no time for a meal. So that's why I have always lived alone-it's a lot of fun. And new girls come in, they try-all alone, like a castaway-to find a friend, a partner. And I am both alone and with everyone; it's the easiest way. I've had one "odnokhlebka," that's it.

(Nadya, 34, prison term: 9 years)

One of the most popular themes in female intimacy is cheating and betrayal. Cheating means finding another partner in the colony. Betrayal relates to one partner being discharged first. Usually, everyone promises to wait, visit and be faithful, but there were more stories about betrayal than about faithfulness. This moment may become critical for one's adjustment to "normal" life, especially if the person in question has drug issues:

My friend was still in prison. I used to drop by, well, bring packages ... The friend I used to live with ... well, it's really bad. I mean, I am going through a betrayal now; she, she's betrayed me. I have just found out recently . . . I trust people too much. Get burnt and trust again. And I believe them 100\%. I got a word from there. Well, there had been rumors before, too. They called me, told me: "Don't come. Well, don't be stupid. You bring her care packages. It's just for show. Don't," she said, "Don't come." ... no names, nothing-just told me not to come. That's it. But I still thought that maybe they are just talking rubbish ... turned out, it was true ...

(Oksana, 33, prison term: 5 years 3 months)

Close (although not necessarily sexual) relationships are often interfered with by commercial interests, as when someone "narcs out" a friend (for example, reports some prohibited practices), commits fraud in order to receive parole points, or sets the score with someone and establishes her own rules. Interviewees talked about the practice of love "scams," meaning that someone wins the love of another inmate (most often, "patsany" are the ones who take advantage of such scams) in order to live at someone else's expense, have certain privileges, and guaranteed daily care and assistance.

Practices of courtship and displays of affection have their own contextual codes. Many people may read such codes, but they remain cryptic - a private, personal matter in the open repressive space of general guilt and violence:

Cards are really valued in prison because you can use them as a hint, and now there are especially many cards with special meaning. Well, like, "miss you"-anything 
like that. Well, it depends on the stage of the relationship, how far it has gone already. Or there are a lot of cards with meaningful jokes ... And, well, you can put it, like, in your bag if they mean something to you; well, yeah, you can't put it on display, with the police and everything. Well, if you care, you keep them ... If you don't... I threw them away.

(Oksana, 33, prison term: 5 years 3 months).

Homosexual relationships are persecuted and may result in a very severe punishment, on the one hand, and on the other, they are informally legitimate; everyone knows they exist. These relationships are a space for real feelings, an exchange (not necessarily equal), and a power resource, all at the same time. Couples that do not have a special status in prison are in constant danger because they may be reported and put in punitive isolation cells, which leaves them with no chance of parole. As to those who rank higher (blatnye, activists, or "sherst"), they are allowed to have such relationships. This is where the gap between gender and regime power closes. Discussion of intimacy is a kind of prison tabloid. The news is discussed both in the barracks and in the administration offices, yet it is still prohibited, and the punishment is too severe to ignore it completely. There are special techniques of protecting these relationships, which, of course, are not available to everyone, but only to those with resources of power:

People were reported only when they were actually seen on a bunk together. So, they write this report.... it is a very nasty, grave report.... it always comes up when you apply for parole. Even if it is three years old. So, everything happens when the police is not there. And when they go into the house, there is a girl on guard, and if she sees them come, they shout all around the house that the police are there, warning everyone.

(Zhenya, 28, prison term: 6.5 years)

One of the most controversial and problematic questions is that of the nature and the source of sexual desire (giving it a name and direction), as well as the factors and sources of homosexual identity formation: is it biological or social, inherent or acquired?

It was my way of escape, falling in love there. It's just that when you . . . you see everything in a different light, you understand that you can be happy anywhere, even here.... When a woman lives there with another women, it's easier, and it isn't just about sex, it's about some sort of well-being. Though, sex is important as well because it relieves stress, even though sometimes, on the contrary, it makes it worse, because it is still not normal under these conditions. ... The only thing that helps you survive and not lose yourself is ... when you don't just think about yourself, but also about another person next to you; then you don't just survive, you don't lose yourself. Because if you only think about yourself, you might just become obsessed and go mad or become a real asshole.

(Galya, 36, prison term: 3 years). 


\section{Discussion and Conclusion}

It can be seen that the rules and regulations of female prison experience, on the one hand, reproduce homophobic sentiments typical of the "free" life, and on the other, include a system of "excuses" that stem from the forced nature of the prison lifestyle. Prisons and colonies are constructed as a "male" space, not in the biological, but in the social, sense, with a strictly patriarchal gender order. "The man," an undisputed, powerful, though temporary authority, is the one who has access to significant resources.

One of the features of the female homosexual experience in prison is its romanticization, which consists of the fear of being discovered and, at the same time, the display of affection (gifts or cards with meaningful hints, kissing, or dating); the formal prohibition of "lesbianism" that some colonies comply with and romantic love stories of female guards and inmates; the acute and tender perception of sensuality and violent fights; and the fidelity of those inseparable couples who help in dealing with everyday needs (water, hygiene, food), and those engaged in open cheating and betrayal. This creates a very particular atmosphere of courage, toughness, and insubordination. However, unlike a soap opera or a TV show, all the characters and victims are real. The closed nature of the prison lifestyle, its regime of violence and repression, the violation of human dignity by legitimate authorities, and the suppression by the internal authority of activists, blatnye, and colony leaders builds up the intensity of passion, and teach inmates to live in a state of constant risk.

At the same time, these rules cannot be trusted fully, that is, they should not be mistaken for real life. Many inmates explained that the most important thing for them was not to get used to the prison lifestyle, and not to start thinking that what was happening to them was real life. This is prison, and therefore it cannot be real. The sincerity of desire, faithfulness in love, vows and promises becomes dramatically real on the one hand, and temporary and changeable on the other. Female intimacy, including friendship, eroticism, sex and sexualized practices, becomes almost the only accessible (albeit dangerous) space of free will, as well as a way of maintaining one's self-esteem, a way of remembering that you are a human being, and a way of exercising your right to be in control of your own female body. However, prison reality often (if not always) bursts into this space in the form of betrayal, reports, cheating, "scams," deceit, and violence.

The gender dimension of women's life in prison is a difficult and extremely sensitive topic for both the research and subsequent interpretation and analysis. When we talk about the gender dimension of the feminine, it is obvious that the categories of the female and femininity are the focus of not only attention, but also criticism. In prison, women's networks of emerging and splitting families and couples, affection, and sexual relations existing in an all-encompassing publicity, an atmosphere of suspicion, danger, risk, distrust, and deceit, and the practices of the exchange of goods, services, and feelings are vital for survival. Not everyone is involved in these relationships, but all female inmates take part in various activities, supervision, and control, at least to some extent. Women's statuses entail different types of power. Below is a description of the main branches of 
power that are based on the stories that were heard. The vector of official power suggests a hierarchy that goes from free women to female inmates (as a separate subtype: from free men, such as plumbers, locksmiths, and so on, to female inmates). In terms of the vector of semi-official power, this extends from real authorities (the warden, medical staff, and security officers) to self-regulatory (female inmates that have become activists, brigade leaders, and inmates on duty). Based on outside and pre-prison resources, power goes from those who receive care packages to those who do not. In terms of generations, power goes from habitual offenders to first-timers, and also from long prison terms to shorter ones. Another branch of power is based on sexual/gender identities and activities. It is difficult (and hardly appropriate) to talk about the extent of female power in this intertwined space. Women's power is incredibly fractional; its hierarchy is very fluid and dominant, and subordinate roles and statuses are temporary, unstable, and unreliable.

Understanding the feminine in prison makes the contradiction between the role of the "eternal woman" as the protector and the "guardian" of public morals and ethics, its inherent extreme vulnerability and purity, and the actual display of the female in a variety of gender regimes in the context of regulatory practices of tough discipline and punishment systems all the more apparent. The reproduction of the topic of "betrayal" prescribed by the natural female destiny in analyses of female criminality in general, and the features of women's imprisonment in particular, is typical for even less popular images. More or less harsh interpretations of this topic can be found in both political discourse and academic debate. Here, female criminality is reduced to biology that is expressed through women's refusal to act in accordance with their biological fate and their sociosexual body that belongs both to a man (the family as a social unit) and to the state (the reproduction of the nation). As a result, women in prison do not only break the law, but also violate gender expectations; if they take part in homosexual relationships, they destroy the very notion of "the female" as a mandatory and subordinate counterpart of "the male." Thus, such a woman is considered different in three ways: she is "not a real woman," "not a real criminal," and "not a real pervert."

The penal system for female inmates is built not only in accordance with the law in the sense of regulations on measuring the degree of an offence and its danger to society, but also according to the principles of gender violations. Therefore, female criminals, being "not-a-woman" in three different ways, are deprived of their basic social benefits and respective practices of the care of the feminine, treatment of the feminine, and recognition of the feminine. Prison policy aims to suppress and sometimes even to "kill" inmates' femininity. It is a kind of a social castration of "wrong" and "fake" female bodies, which counts neither on physiological compliance (they should not menstruate, experience sexual desire and strive for pleasure, and should not/cannot give birth) nor on a sociocultural recognition of femininity (the desire/urge to care, to love significant others, and to raise a child). 


\section{Acknowledgments}

I would like to take this opportunity to express my profound gratitude and deep regard to Professor Judith Pallot's valuable feedback and constant encouragement throughout the duration of the project. I am also grateful to Dr. Guzel Sabirova for her assistance and comments. I would also like to give my sincere gratitude to all the informants without whom this research would be incomplete.

\section{References}

Alpern L. (ed.) (2002) Zhenchiny v rossyskoy tyurme: problem, svidetel'stva, vzglyad iznutri [Women in Russian Prison: Problems, Evidences, View from Within], Moscow: Obshchestvennyj zentr sodeystviya reforme ugolovnogo pravosudiya.

Alpern L. (2004) Son i yav'zhenskoy tyur'my [Dream and Reality in Women's Prisons], Saint Petersburg: Aleteya.

Antonyan Y., Kolyshnizyna E. (2009) Motivaziya povedeniya osuzhdennyh [Motives of Convict's Behavior], Moscow: Yuniti.

Baro A. L. (1997) Spheres of Consent: An Analysis of the Sexual Abuse and Sexual Exploitation of Women Incarcerated in the State of Hawaii. Women and Criminal Justice, vol. 8, no 3, pp. 51-84.

Essig L. (2014) "Bury Their Hearts": Some Thoughts on the Spectre of Homosexuality Haunting Russia. QED: A Journal in GLBTQ Worldmaking, vol. 1, no 3, pp. 39-58.

Fishman J. F. (1934) Sex in Prison: Revealing Sex Conditions in American Prisons, New York: National Library Press.

FPS (2016) Kratkaya harakteristika ugolovno-ispravitel'noy sistemy [Brief Desription of the Penal System]. Available at: http://www.fsin.su/structure/inspector/iao/statistika/ Kratkaya\%2ohar-ka\%2oUIS/ (accessed 15 May 2016).

Greer K. R. (2000) The Changing Nature of Interpersonal Relationships in a Women's Prison. Prison Journal, vol. 8o, no 4, pp. 442-468.

Gusejnova D. (2013) Shopping at Sizomag: The Internet as a Potemkin Village of Modern Russian Penal Practice. Laboratorium: Russian Review of Social Research, vol. 5, no 3, pp. 90-118.

Healey D. (2002) Homosexual Existence and Existing Socialism: New Light on the Repression of Male Homosexuality in Stalin's Russia. GLQ: A Journal of Lesbian and Gay Studies, vol. 8, no 3, pp. 349-378.

Hensley Ch., Struckman-Jonson C., Eigenberg H. M. (2000) Introduction: The History of Prison Sex Research. Prison Journal, vol. 8o, no 4, pp. 360-367.

Irwin J., Cressey D. R. (1962) Thieves, convicts and the inmate culture. Social Problems, vol.10, pp. 142-155.

Katz E., Pallot J. (2010) From "Femme Normale" to "Femme Criminelle" in Russia: Against the Past ir Towards the Future? New Zealand Slavonic Journal, vol. 44, pp. 111-139. 
Kon I. (2003) Lunnyj svet na zare: liki i maski odnopoloy lyubvi [Moonlight at Dawn: Faces and Masks of Same-Sex Love], Moscow: Olimp.

Kunzel R. (2008) Criminal Intimacy: Prison and the Uneven History of Modern American Society, Chicago: University of Chicago Press.

Lacombe D. (2008) Consumed with Sex: The Treatment of Sex Offenders in Risk. British Journal of Criminology, vol. 48, no 1, pp. 55-74.

Gibson L. E., Hensley Ch. (2013) The Social Construction of Sexuality in Prison. Prison Journal, vol. 93, no 3, pp. 355-370.

Mondimore F. M. (1996) A Natural History of Homosexuality, Baltimore: Johns Hopkins University.

Moran D., Pallot J., Piacentini L. (2009) Lipstick, Lace, and Longing: Constructions of Femininity Inside a Russian Prison. Environment and Planning D: Society and Space, vol. 27, no 4, pp. 700-720.

Moran D., Pallot J., Piacentini L. (2013) Privacy in Penal Space: Women's Imprisonment in Russia. Geoforum, vol. 47, pp. 138-146.

Oleynik A. (2001) Tyuremnaya subkul'tura v Rossii: ot povsednevnoy zhizni do gosudarstvennoy vlasti [Prison Subculture in Russia: From Everysay Life to State Power], Moscow: INFRA-M.

Omelchenko E. (ed.) (2012) Do i posle tyrjmy: zhenskie istorii [Before and After Prison: Women's Stories], Saint Petersburg: Aleteya.

Omelchenko E., Pallot J. (eds.) (2015) Okolo tjur'my: zhenskie seti podderzhki zakljuchennyh [Close to Prison: Women's Networks of Prisoners Support], Saint Petersburg: Aleteya.

Omelchenko E., Sabirova G. (2013) Vozvrashenie? (Post)penitenziarnyj opyt molodyh zhenchin ["Coming Back"? (Post)carceration Experience of Young Women]. Journal of Social Policy Studies, vol. 10, no 4, pp. 485-504.

Omelchenko E. (1999) New Dimensions of the Sexual Universe: Sexual Discourses in Russian Youth Magazines. Gender and Identity in Central and Eastern Europe (ed. C. Corrin), London: Frank Cass, pp. 99-133.

Omelchenko E. (200o) My Body, My Friend? Provincial Youth Between the Sexual and the Gender Revolutions. Gender, State and Society in Soviet and Post-Soviet Russia (ed. S. Ashwin). Routledge: London, pp. 137-167.

Omelchenko E. (2015) Between Us Girls: On Girls' Interpretations of Sexuality. Girlhood Studies, vol. 8, no 1, pp. 110-125.

Pallot J., Piacentini L. (2012) Gender, Geography, and Punishment: The Experience of Women in Carceral Russia, Oxford: Oxford University Press.

Pallot J., Katz E. (2014) The Management of Prisoners' Children in the Russian Federation. Howard Journal of Criminal Justice, vol. 53, no 3, pp. 237-254.

Pallot J., Piacentini L., Moran D. (2010) Patriotic discourses in Russia's penal peripheries: Remembering the Mordovan Gulag. Europe-Asia Studies, vol. 62, no 1, pp. 1-33.

Pallot J. (2005) Russia’s Penal Peripheries: Space, Place and Penalty in Soviet and Post-Soviet Russia. Transactions of the Institute of British Geographers, vol. 30, no 1, pp. 98-112. 
Pardue A., Arrigo B. A., Murphy D. S. (2001) Sex and Sexuality in Women's Prisons: A Preliminary Typological Investigation. Prison Journal, vol. 91, no 3, pp. 279-304.

Piacentini L. (2004) Penal Identities in Russian Prison Colonies. Punishment \& Society, vol. 6, no 2, pp. 31-147.

Piacentini L., Pallot J., Moran D. (2009) Welcome to Malaya Rodina ("Little Homeland”): Gender and Penal Order in a Russian Penal Colony. Social \& Legal Studies, vol. 18, no 4, pp. 523-542.

Smith B. V. (2006) Rethinking Prison Sex: Self-expression and Safety. Columbia Journal of Gender and Law, vol. 15, no 1.

Stella F. (2008) Homophobia Begins at Home: Lesbian and Bisexual Women's Experiences of the Parental Household in Urban Russia. Kul'tura, no. 2, pp. 12-17.

Stella F. (2010) The Language of Intersectionality: Researching "Lesbian" Identity in Urban Russia. Theorizing Intersectionality and Sexuality (eds. Y. Taylor, S. Hines, M. E. Casey), Houndmills: Palgrave Macmillan, pp. 212-234.

Stella F., Nartova N. (2015) Sexual Citizenship, Nationalism and Biopolitics in Putin's Russia. Sexuality, Citizenship and Belonging: Trans-National and Intersectional Perspectives (eds. F. Stella, Y. Taylor, T. Reynolds, A. Rogers), London: Routledge, pp. 24-42.

Struckman-Johnson C., Struckman-Johnson D., Rucker L., Bumby K., Donaldson S. (1996) Sexual Coercion Reported by Men and Women in Prison. Journal of Sex Research, vol. 33, no 1, pp. 67-76.

Temkina A., Zdravomyslova E. (2003) Gender Studies in Post-Soviet Society: Western Frames and Cultural Differences. Studies in East European Thought, vol., 55, no 1, pp. 51-61.

Temkina A., Zdravomyslova E. (2014) Gender's Crooked Path: Feminism Confronts Russian Patriarchy. Current Sociology, vol. 62, no 2, pp. 253-27o.

Tishchenko N. (2007) Gendernye aspekty tyuremnoy subkul'tury v sovremennoy Rossii [Gender Aspects of the Prison Subculture in Contemporary Russia], Saratov: Nauka.

Ward D., Kassebaum G. G. (1964) Homosexuality: A Mode of Adaptation in a Prison for Women. Social Problems, vol. 12, no 2, pp. 159-177.

Wilkinson C. (2013) Putting “Traditional Values” Into Practice: Russia's Anti-gay Laws. Russian Analytical Digest, no 138, pp. 5-7.

Yasaveev I. (2010) "Sizhu za reshetkoy": mediaobrazy rossiyskih zaklyuchennyh ["Behind Bars": Media Representations of Prisoners in the Russian Federation]. Journal of Social Policy Studies, vol. 8, no 1, pp. 53-68. 


\section{Гендер, сексуальность и близость в российских женских колониях}

\section{Елена Омельченко}

Доктор социологических наук, директор Центр молодежных исследований Национального исследовательского университета «Высшей школы экономики» в Санкт-Петербурге Адрес: ул. Союза Печатников, д. 16, г. Санкт-Петербург, Российская Федерация 190008 E-mail: eomelchenko@hse.ru

В статье рассматриваются режимы близости и сексуальности в российских женских колониях. Российская пенитенциарная система в целом и, опыт осужденных женщин, женские идентичности и практики наказания редко оказываются в фокусе интереса отечественных исследователей, оставаясь в пространстве маргинализации и отсутствия критического общественного обсуждения и социального исследования. Данная статья является вкладом в актуальные дискуссии о значении и последствиях близких отношений в колонии, контекст которых варьируется от дружеских и любовных - до использования и эксплуатации при жестком контроле гендерного режима, как со стороны администрации, так и неформальной системы власти, характерной для внутритюремной иерархии колонии. Женское тело становится дополнительным механизмом поддержания репрессивного характера исправительной колонии, укрепления патриархальных устоев и поддержания высокого уровня гомофобии в российском обществе в целом. Эмпирической базой анализа стали 33 глубинных интервью с элементами биографического с женщинами от 18 до 55 лет, отбывавших наказание по разным статьям (распространение наркотиков, кража, мошенничество, убийство). Я утверждаю, что гендерный режим в исправительных учреждениях для женщин становится дополнительным механизмом усиления патриархатного режима в российском обществе. Несмотря на то, что режим не предусмотрено законом, оно становится законом из-за крайней объективации женщин, женского тела и женского статуса.

Ключевые слова: российская пенитенциарная система, женские колонии, патриархальный гендерный режим, женское тело, гендер, сексуальность, близость 